\title{
MOURÃO E CAMARGO: UMA ANÁLISE DISCURSIVA DO RACISMO NO GOVERNO BOLSONARO
}

\author{
MOURÃO AND CAMARGO: A DISCURSIVE ANALYSIS \\ OF RACISM IN THE BOLSONARO GOVERNMENT
}

\author{
Maria do Carmo Pereira Gomes Cavalcanti ${ }^{1}$ \\ [https://orcid.org/0000-0002-3158-7209] \\ Nadia Pereira da Silva Gonçalves de Azevedo \\ [https://orcid.org/0000-0001-6425-2846] \\ DOI: 10.30612/raido.v15i37.13817
}

\begin{abstract}
RESUMO: Este artigo movimenta um gesto de leitura, interpretaçăo e análise sobre o discurso de Sérgio Camargo e de Hamilton Mouráo acerca da morte de um cliente no Carrefour em Porto Alegre. Assim, utilizando os postulados teóricos e analíticos da Análise do Discurso de linha francesa, delineada por Pêcheux na Europa e desenvolvida no Brasil por Orlandi e demais estudiosos, este trabalho mobiliza as noçóes de sujeito, memória discursiva, formaçâo discursiva, formaçâo imaginária, denegaçăo discursiva no discurso de Mourâo e no discurso do Presidente da Fundaçăo Palmares Sérgio Camargo que funcionam como unidades de sentido em relaçăo à situaçăo. Interessa analisar o racismo, a posiçấo-sujeito ocupada por cada político que enuncia, afetado pelas formaçōes imaginárias, inscrito em uma formaçâo discursiva, que determina o que pode e deve ser dito e que regula sobre como devem se manifestar em público um dos chefes do poder executivo e o representante dos afro-brasileiros que deveriam ser exemplos de líderes políticos do país e do povo.
\end{abstract}

Palavras-chave: Discurso. Racismo. Política.

ABSTRACT: This paper moves a gesture of reading, interpretation and analysis about the discourse of Sérgio Camargo and Hamilton Mourăo about the death of a client at Carrefour in Porto Alegre. Thus, using the theoretical and analytical postulates of the Discourse Analysis of the French line, outlined by Pêcheux in Europe and developed in Brazil by Orlandi and other academics, this work mobilizes the notions of subject, discursive memory, discursive formation, imaginary formation, discursive denial in Mourăo's discourse and in the discourse of the President of the Palmares Foundation Sérgio Camargo that function as units of meaning in relation to the situation. It is interesting to analyze racism, the position-subject occupied by each politician who enunciates, affected by imaginary formations, inscribed in a discursive formation, which determines what can and should be said and that regulates how one of the heads of the executive power and the representative of afro-Brazilians who should be examples of political leaders of the country and the people should be manifested in public.

Keywords: Discourse. Racism. Politic.

\footnotetext{
1 Doutora em Ciências da Linguagem (Unicap).

2 Professora e Pesquisadora do Programa de pós-graduaçăo em Ciências da Linguagem (Unicap).
} 


\section{CONSIDERAÇÕES INICIAIS}

A morte de Joáo Alberto Ferreira de Freitas repercutiu nacionalmente e foi divulgada em redes sociais e diferentes emissoras. O Jornal Hoje, da Rede Globo de Televisâo, exibido em vídeo e de forma virtual, criado em 1971, exibido à tarde semanalmente, apresentou em uma reportagem intitulada: 'no Brasil năo existe racismo', diz Mourăo sobre assassinato de homem negro em supermercado ${ }^{3}$. Nela, consta que Mourâo afirmou ser lamentável o acontecimento no Carrefour, mas o fato nâo se relaciona a racismo. O soldador Joăo Alberto Freitas, 40 anos, negro, foi espancado por dois seguranças brancos e presos em flagrante. O presidente da fundaçăo Cultural Palmares, Sérgio Camargo asseverou que năo há racismo 'estrutural' no Brasil, mas circunstancial ${ }^{4}$.

No site do jornal Correio Brasiliense, aparece intitulada a reportagem: “homem negro é espancado e morto por segurança e policial militar em Carrefour de Porto Alegre". Na noite do dia 19 de novembro de 2020, véspera da Consciência Negra, aconteceu uma tragédia em uma das unidades do Carrefour localizada em Passo D' Areia, Porto Alegre. Joáo Alberto Ferreira de Freitas, segundo o delegado Leandro Bodoia, teria se desentendido com funcionários do supermercado enquanto passava as compras no caixa. A vítima fez 'gestos agressivos' e foi conduzido pelos seguranças para fora da loja e espancado até a morte.

O ministro do Supremo Tribunal Federal (STF), Gilmar Mendes, afirma que a luta contra o racismo está longe de acabar. O site Brasil de fato traz a manchete de capa: "Sete vezes em que o Carrefour atuou com descaso", que aborda atitudes de violência por parte de seguranças do Carrefour há muito tempo. A reportagem evidencia por exemplo, o fato ocorrido em 2009, em que seguranças agrediram o vigia e técnico em eletrônica Januário Alves de Santana por confundi-lo com um ladrăo e acusá-lo de roubar o próprio carro. Em 2018, um dos funcionários do Carrefour em Sảo Bernardo do Campo no ABC Paulista, agrediu Luís Carlos Gomes por ele abrir uma lata de cerveja. Mesmo afirmando que iria pagar, foi perseguido pelo gerente e um segurança. Em seguida, recebeu um "mata-leâo" em um banheiro.

Diante de algumas denúncias em relaçăo à rede de supermercados Carrefour, em particular o acontecimento do dia 19/11/2020, que comoveu o país, é preciso pontuar que este artigo náo pretende aprofundar-se na questăo do racismo estrutural, mas analisar como a posiçấo-sujeito de vice-presidente do Brasil funciona discursivamente neste vídeo, interpelado pela ideologia racista, bem como o discurso do presidente da Fundaçâo Palmares.

Para analisar o discurso de Hamilton Mourâo e Sérgio Camargo, as seguintes questóes de pesquisa se fizeram presentes: como as formaçóes discursivas e imaginárias do vice-presidente e do presidente da Fundaçăo Palmares se mostram nessas reportagens? Como a memória discursiva é acionada nos respectivos discursos? É possível se observar o funcionamento da denegaçăo?

3 Matéria de 20/11/2020, disponível no site do g1 globo, em: https:/g1.globo.com/ politica/ noticia/2020/11/20/mourao-lamenta-assassinato-de-homem-negro-em-mercado-mas-diz-que-nobrasil-nao-existe-racismo.ghtml).

4 As concepçôes de racismo serâo trabalhadas nas consideraçôes teóricas. 
Para responder a tais questionamentos, este trabalho destina-se a analisar um corpus constituído por publicaçôes em sites e na reportagem exibida em vídeo pela TV Globo. Este artigo está distribuído, de forma a apresentar ao leitor as consideraçóes iniciais, marcando problematizaçóes e objetivos. Num segundo momento, pretende tecer algumas consideraçóes teóricas sobre o racismo estrutural. Em seguida, trazer algumas consideraçōes de noçôes operatórias acerca do dispositivo teórico e analítico, suporte deste trabalho, a Análise do Discurso de orientaçăo francesa, tal como delineada por Pêcheux e desenvolvida, no Brasil, por Orlandi e outros estudiosos. Num quarto momento, mostra-se o percurso metodológico do trabalho. Em seguida, há uma discussâo sobre o corpus discursivo da matéria jornalística em estudo, com ênfase no aspecto da posiçăo sujeito, como lugares sociais inscritos na historicidade pela exterioridade constitutiva. Por último, haverá o efeito de fechamento do trabalho, com as consideraçōes finais.

\section{O RACISMO ESTRUTURAL NA SOCIEDADE CONTEMPORÂNEA}

Desde a época colonial o homem negro é humilhado, desonrado, transmutado em 'coisa' e isto permanece no século XXI. Existe um contínuo esforço da populaçâo branca em conferir aos afrodescendentes o estatuto de inferiores em todos os âmbitos da sociedade, abstraindo-lhes a humanidade, num esforço constante de salvaguardar a permanência de relaçôes escravistas (MBEMBE, 2014). O negro é ainda aquele "que vemos quando nada se vê, quando nada compreendemos. Em qualquer lado onde apareça, o negro liberta dinâmicas passionais e provoca uma exuberância irracional que tem abalado o próprio sistema racional" (MBEMBE, 2014, p.11).

A raça é uma das matérias primas com as quais fabricamos a diferença e o excedente, isto é, uma espécie de vida que pode ser gasta ou passada sem reservas. Pouco importa que ela năo exista enquanto tal, e năo só devido à extraordinária homogeneidade genética dos seres humanos. Ela continua a produzir efeitos de mutilaçấo, porque, originariamente, é e será sempre aquilo em nome do qual se operam fissuras na sociedade[...] (MBEMBE, 2014, p.70).

A raça, desde tempos remotos, póe os sujeitos em lugares díspares e "conserva" de forma velada ou nâo a "superioridade" branca em relaçăo aos negros. A raça possibilita identificar determinadas populaçôes, possuidores de características peculiares. Os processos de racializaçâo procuram marcar esses grupos, demarcando limites nos quais é permitido transitar, espaços que podem ocupar, conduzindo a circulaçăo numa direçấo que afaste ameaças e assegure proteçâo geral (MBEMBE, 2014). Os negros antecipadamente sáo representados como ameaça, perigo, quando em muitos momentos săo vítimas do racismo.

Grande parte da sociedade tem a crença de ter construído uma naçăo diferente náo caracterizada por embates raciais abertos como nos Estados Unidos, África do Sul. As políticas de açâo afirmativa buscam por meio de um tratamento provisoriamente diferenciado, suscitar a equidade entre grupos. O mito da democracia racial buscava um ideal de homogeneidade, o que implicava que os racialmente diferentes năo seriam bem "aceitos". Em 1996, Fernando Henrique Cardoso, na época presidente da República, na abertura de um seminário intitulado: multiculturalismo e 
racismo, afirmou que o país era racista. No mesmo ano, ao divulgar o Plano Nacional dos Direitos Humanos incluiu como um de seus objetivos "açôes afirmativas" 5 para o acesso dos negros a cursos profissionalizantes, áreas de tecnologia de ponta, à universidade (BERNARDINO, 2002).

O mito da democracia racial decorreria do processo de miscigenaçấo, no entanto, a năo segregaçấo de raças pela perspectiva biológica năo implicava a equidade do ponto de vista social. "[...] a recusa de reconhecer a realidade da categoria raça, tanto num sentido analítico quanto de intervençâo pública, fez do regime de relaçôes raciais brasileiro um dos mais nefastos e estáveis do mundo ocidental" (BERNARDINO, 2002, p. 256). O Brasil naturalizou o racismo, dentre outros preconceitos.

As cotas em universidades, por exemplo, fazem parte de políticas públicas que buscam corrigir desigualdades sociais oriundas da postura discriminatória no passado e/ou presente baseados na raça (BERNARDINO, 2002). Outrossim, até mesmo nas puniçóes simbólicas existem diferenças entre raças. Năo é comum alguém falar "branco safado." "[...] todos sabem a quem se dirigem os insultos" negro safado", "negro nojento", "só podia ser negro" etc., assim como a polícia também sabe quem é negro [...]". Conforme o autor, o racismo só faz sentido e encontra espaço dentro de um sistema classificatório racial, que opóe e hierarquiza as raças.

Segundo Nunes (2006), o Brasil foi o último país a abolir a escravidāo. Há tentativas de apagar a barbárie, seja pela destruiçáo de documentos, seja pelo mito da democracia racial. O Estado sempre foi omisso em relaçāo ao assunto, e através da conduçâo ideológica transmutou o que é do âmbito das relaçōes de poder para algo "normal" inerente à raça. Apesar do discurso que nega ou suaviza a discriminaçấo racial, năo é incomum haver manifestaçôes racistas no cotidiano. Ora o racismo é declarado como nos massacres, silencioso como o olhar policial que continuamente coloca os negros sob suspeita.

O mito da democracia racial apoia-se no fato de que a sobrevivência de traços da cultura africana na sociedade brasileira teria resultado de relaçóes amigáveis entre senhores e escravos. Cançôes, presentes, comida, linguagem seriam indicadores da ausência de preconceito e discriminaçâo no Brasil. As relaçōes fortuitas e concubinagem entre brancos e negros tinha como "finalidade" o branqueamento da raça. De fato, os homens negros e mulheres negras, năo podiam entrar pela "porta da frente", pois eram vistos como mera força de trabalho, criminosos e prostitutas. A convicçăo de alguns de que as relaçóes raciais no Brasil săo de qualidade superior quando cotejada com os Estados Unidos, geralmente se ancora na suposta teoria de saudável interaçáo sexual “[...] as classes dirigentes e autoridades públicas praticavam a libertaçâo de escravos inválidos, idosos, enfermos incuráveis, sem lhes conceder qualquer recurso, apoio ou meio de subsistência [...]" (NASCIMENTO, [1978], 2016).

O presidente Getúlio Vargas, em 18/09/1945 instituiu o decreto lei número 7967, estimulando a entrada de imigrantes brancos europeus no Brasil. A ideia de branqueamento se fortalecia. Em 1899, o ministro das finanças Rui Barbosa ordenou a incineraçăo de todos os documentos, inclusive registros demográficos, financeiros, estatísticos

5 Sâo políticas públicas que tencionam corrigir as desigualdades econômicas e sociais oriundas de discriminaçăo atual ou histórica, sofrida por algum grupo de pessoas. 
pertinentes à escravidăo, ao tráfico negreiro. Isto impossibilitaria uma análise de grande marco histórico, como se pudesse apagar a presença do negro no Brasil. Mesmo após a lei Afonso Arinos, que proibia a discriminaçăo racial, permaneceu comum em anúncio de empregos năo se aceitarem pessoas de cor. O Apartheid, por exemplo é uma política segregacionista, mas semelhante à democracia racial. Separada em métodos e geografia, mas iguais em efeitos nocivos. Desde a década de 1960, o Brasil procura passar internacionalmente a ideia de năo ser racista (NASCIMENTO, 1978).

Conforme Almeida (2018, p. 25), existem diferenças entre racismo, preconceito e discriminaçấo.

[...] racismo é uma forma sistemática de discriminaçâo que tem a raça como fundamento, e que se manifesta por meio de práticas conscientes ou inconscientes que culminam em desvantagens ou privilégio para indivíduos, ao depender do grupo social ao qual pertençam. O preconceito é proveniente de estereótipos acerca de indivíduos de certo grupo social. A discriminaçăo é o tratamento diferenciado atrelado a determinadas raças.

Há três concepçôes de racismo: a individualista, a institucional e a estrutural. A última é a que atravessa nossas relaçōes sociais. Na concepçăo individualista năo se assume a existência do racismo, mas do preconceito, a fim de enfatizar a perspectiva psicológica do fenômeno em detrimento de sua natureza política. Nessa diretriz, nâo existe racismo na sociedade, mas indivíduos racistas. Na concepçăo institucional a dinâmica do funcionamento das instituiçôes confere, ainda que indiretamente, privilégios e desvantagens a partir da raça. As instituiçôes săo dominadas por certos grupos raciais que lançam măo de mecanismos institucionais para impor seus interesses econômicos e políticos. As instituiçōes săo racistas porque a sociedade também é. Há um predomínio de homens brancos em instituiçôes públicas como: em reitorias, no poder Legislativo, no Judiciário, Ministério Público, em que existem regras e padróes que direta ou indiretamente torna-se óbice para ascensâo de negros e/ou mulheres (ALMEIDA, 2018).

A matéria, do site sinprodf.org.br, intitulada: “Negros ocupam apenas um décimo das cadeiras no poder legislativo do Brasil" aponta que apesar que apesar do povo negro representar mais da metade da populaçáo (56,1\% dos brasileiros sâo pretos e pardos, segundo o Instituto Brasileiro Geografia e Estatística (IBGE)), apenas um décimo ocupa cadeiras no Poder Legislativo, Câmara dos Deputados, formado pelo Senado, assembleias legislativas e câmaras de vereadores.

Os dados, que mostram um contraste entre o total de candidatos negros a (em cargos, ou talvez ocupando cargos) cargos no Poder Legislativo em relaçăo ao total da populaçáo que se declara negra ou parda, deixando emergir que persiste o racismo estrutural em todas as relaçôes de poder no país, preservando o longo processo de desigualdade entre brancos e negros.

Para o senador Paulo Paim (PT-RS), é necessário aumentar as candidaturas de negros. Ele diz que, para isso, os partidos precisam criar alternativas de inclusăo que realmente funcionem.

"Precisamos fomentar e fortalecer as candidaturas negras para todos os pleitos eleitorais, inclusive para cargos no executivo", afirmou o senador, que 
os partidos precisam incluir a ampliaçăo da presença das mulheres e negros nos lugares de poder de forma mais equânime.

O racismo faz parte da estrutura social, da forma 'normal' como se constituem as relaçóes econômicas, políticas, sociais, familiares e prescinde de intençăo. Calar-se diante do racismo torna o indivíduo ética e politicamente responsável pela preservaçăo deste. No Brasil existe uma negaçâo do racismo e o mito da democracia racial amparados pelo discurso da meritocracia. O que funciona no imaginário da grande maioria é que se nâo há racismo, a culpa pela própria condiçâo social é das pessoas negras, que nâo fizeram tudo que deveriam para alcançar seus objetivos. A meritocracia legitima a miséria, a violência, a desigualdade num país já bastante desigual e se torna obstáculo para decisóes políticas efetivas no combate à discriminaçăo racial, principalmente por parte do poder estatal (ALMEIDA, 2018).

A palavra produz efeitos de sentido de acordo com as formaçôes discursivas a que pertence. O discurso racista encontra "acolhida" na sociedade, se de certa forma, esta for racista (POSSENTI, 1995). O racismo é escamoteado pelo mito da democracia racial. Poucos săo os negros que conseguem galgar um cargo importante como juiz, reitor, dentre outros. A grande maioria possui um trabalho precário, mora em periferia, está em presídios. A sociedade estranha quando vê um médico negro e um mendigo louro. A mudança da sociedade náo acontece apenas por denúncias ou repúdio moral ao racismo. A priori, depende de tomada de posiçáo e adoçáo de práticas antirracistas (ALMEIDA, 2018).

Conforme Modesto (2018) negar ou ignorar as tensōes raciais que existem nas sociedades ocidentais, como se as opressôes resultassem de desigualdades sociais, é uma forma de recrudescer o racismo negando sua existência. O processo de situar o negro em determinados lugares ativa um funcionamento que faz com que o próprio negro se veja em certas posiçóes enquanto sujeitos. Quando por exemplo, vislumbrando uma intervençấo policial, alguém diz 'parado'! é provável que apenas sujeitos negros olhem para quem os chama, pois existe uma ênfase no negro como culpado. A presença policial para alguns significa proteçáo, para outros, medo. Essa presença nos locais onde estâo os negros apavora, oprime (SANTOS, 2018).

O imaginário social acerca do "ser negro", carrega um preconceito historicamente constituído que reverbera nos dias atuais de forma multifacetada e se materializa em posicionamentos que enaltecem uma supremacia branca e inferiorizam os afrodescendentes. Partindo do que foi dito, no próximo item mobilizaremos as noçóes operatórias de sujeito, formaçâo discursiva, formaçáo imaginária, memória discursiva e denegaçăo discursiva, para analisar os discursos de políticos que impactam a sociedade.

\section{SUJEITO, FORMAÇÃO DISCURSIVA, FORMAÇÃO IMAGINÁRIA, MEMÓRIA DISCURSIVA, DENEGAÇÃO DISCURSIVA}

É importante ressaltar que a partir de Pêcheux (1969) discurso passa a ser compreendido como efeito de sentido entre locutores. $O$ discurso remete a um discurso prévio, ou seja, o sujeito náo é a fonte do sentido, embora tenha está ilusăo que é constitutiva. Para Orlandi (2013) etimologicamente, discurso tem a ideia de percurso, curso. 
O discurso é a palavra em movimento, é um objeto sócio-histórico em que o linguístico intervém como pressuposto.

O discurso é o lugar em que se pode perceber a relaçâo entre língua e ideologia. Conforme Pêcheux e Fuchs (1975); Pêcheux (2009), náo há discurso sem sujeito e náo há sujeito sem ideologia.

[...] É a ideologia que fornece as evidências pelas quais "todo mundo sabe" o que é um soldado, um operário, um patrăo, uma fábrica, uma greve etc., evidências que fazem com que uma palavra ou um enunciado" queiram dizer o que realmente dizem" e que mascaram, assim, sob a "transparência da linguagem", aquilo que chamaremos o caráter material do sentido das palavras e dos enunciados (PÊCHEUX, [1975], 2009, p. 146).

A ideologia produz efeitos de evidência em relaçăo aos sujeitos, aos sentidos e à situaçăo. Para Orlandi $(1998,2013)$ o sujeito corresponde a um sítio de significaçăo historicamente constituído, uma 'posição'. O sujeito na AD nâo é empírico, nem ocupa lugares objetivos na estrutura social. Conforme Pêcheux (1969, [1983], 2008, [1975], 2009); Pêcheux e Fuchs (1975) Orlandi (2012a 2012b, 2012c, 2007, 2013, 2017) o indivíduo se constitui em sujeito pela interpelaçăo ideológica e pelo discurso do outro e do "Outro" (inconsciente/interdiscurso). A alteridade é constitutiva do discurso.

A noçâo de linguagem que norteia a $\mathrm{AD}$ apresenta contribuiçôes da Psicanálise. De acordo com Ferreira (2010), trazer a Psicanálise para o âmbito da AD significa ter outra concepçâo de sujeito, um sujeito cindido, clivado, assujeitado, desejante, afetado pelo inconsciente e pelas circunstâncias histórico sociais. É interessante enfatizar que o sujeito da psicanálise năo se confunde com o sujeito da $\mathrm{AD}$. $\mathrm{O}$ sujeito da $\mathrm{AD}$ opera com a noçăo de ideologia que náo encontra acolhida na Psicanálise. Para a AD o sujeito se constitui como tal pela submissâo à língua e pela interpelaçâo ideológica. O sujeito assujeitado althusseriano interpelado pela ideologia năo se aproxima do sujeito do inconsciente lacaniano, identificado ao discurso do Outro (inconsciente).

A subjetividade na $\mathrm{AD}$ e a subjetividade em Lacan năo se confundem, porque como Althusser (1985) e Pêcheux (2009) afirmam, a ordem do inconsciente năo se confunde com a ordem da Ideologia, mas elas estăo sim relacionadas. Existe na AD uma subjetividade, no entanto ela năo é subjetiva, ela é independente dos sujeitos e estes nâo sâo sua fonte originária.

É relevante salientar que os discursos produzem sentidos porque se inscrevem em formaçóes discursivas. Segundo Pêcheux ([1975], 2009); Pêcheux e Fuchs (1975) (ressignificando a concepçâo de Foucault) chama-se formaçâo discursiva aquilo que, numa dada formaçâo ideológica, a partir de uma posiçâo e conjuntura dadas, determinada pela luta de classes, determina o que pode e deve ser dito. A formaçâo discursiva é lugar de constituiçấo dos sentidos e identificaçăo dos sujeitos (ORLANDI, 2013). Os indivíduos săo interpelados em sujeitos de seu discurso pelas formaçōes discursivas que representam "na linguagem" as formaçōes ideológicas que lhes săo correspondentes.

[..] As formaçôes ideológicas constituem um conjunto complexo de atitudes e representaçôes, que năo sâo nem "individuais", nem "universais" mas se relacionam mais ou menos diretamente a posiçóes de classes em conflito umas com as outras. 
Uma palavra, proposiçâo, expressâo nâo tem um sentido vinculado a literalidade, mas mudam de sentido de acordo com as posiçōes, formaçóes discursivas e ideológicas sustentadas por aqueles que as empregam (PÊCHEUX, [1975], 2009, p.163).

De acordo com Pêcheux e Fuchs (1975); Pêcheux (1969); Orlandi (2013) toda formaçâo discursiva deriva de condiçôes de produçâo que constituem as formaçôes imaginárias. As condiçôes de produçăo sâo constituídas pelas relaçōes de sentido, pelo mecanismo de antecipaçăo e pela relaçâo de forças. Na relaçâo de sentidos existe a noçăo que todo discurso se relaciona com outros imaginados, possíveis, realizados. 0 segundo mecanismo, na antecipaçăo, o locutor coloca-se no lugar do ouvinte a partir do próprio lugar, de forma que regula o que o sujeito dirá, segundo o efeito que pensa produzir no ouvinte. Na relaçáo de forças, o lugar do qual fala o sujeito é constitutivo do que ele diz. Como a sociedade é hierarquizada, o dizer de um sujeito vale mais do que o de outro a depender da posiçấo sujeito ocupada por cada um. Quando o sujeito enuncia, mobiliza um funcionamento discursivo que remete às formaçôes imaginárias. Estas sâo representaçōes que o sujeito faz de si, do outro, do outro em relaçáo a si, do objeto do discurso. O sujeito tem a ilusâo de que o sentido chega ao interlocutor da forma que espera e isso faz parte da formaçăo imaginária do sujeito falante.

Outra noçăo pertinente a este trabalho é a memória discursiva. Para Pêcheux (1999, p. 52):

[...] a memória discursiva seria aquilo que, face a um texto que surge que surge como acontecimento a ler, vem restabelecer os "implícitos" (quer dizer, mais tecnicamente, os pré-construídos, elementos citados e relatados, discursos-transversos, etc.) de que sua leitura necessita: a condiçăo do legível em relaçăo ao próprio legível [...].

A memória discursiva é constituída por discursos outros que atravessam nossos discursos sem que tenhamos "consciência" disso, ou seja, é uma rede de sentidos dentro de uma FD, e que tende a absorver os acontecimentos, a fim de manter a estabilidade de sentidos dentro da FD. Pêcheux (2009, p. 149) considera interdiscurso como [...] "todo complexo com dominante das formaçóes discursivas". Nesse sentido, o interdiscurso é algo que fala sempre antes, em outro lugar e independentemente, é o retorno do interdiscurso sobre si mesmo, o retorno do discurso do outro na formulaçáo. Conforme Orlandi (2014), quando esquecemos como um discurso se constituiu em nós, a partir daí ele passa a produzir seus efeitos. Retomamos sentidos já existentes. A memória permite recuperar as condiçôes de produçâo dos dizeres e as condiçôes de produçâo permitem reconstituir as condiçôes histórico-sociais entre diferentes formaçóes discursivas (CAZARIN, 2001). A memória é estruturada pelo esquecimento, é o já-dito constituído ao longo da história.

Outra noçăo importante neste trabalho é a denegaçăo. O termo denegaçăo foi introduzido pela psicanálise. Nesta teoria, o sujeito pode ocultar o que foi censurado pelo superego e recalcado no inconsciente, o que nâo lhe possibilitar dizer. Na denegaçấo o sujeito diz sem realmente dizer, apresentando-se cindido "entre o desejo de dizer e sua necessidade de recalcar. A denegaçăo possibilita a verbalizaçấo dessa divisăo, pois o sujeito, ao formular o recalcado negativamente, pode expressá-lo sem, contudo, admiti-lo" (INDURSKY, 1990, p.118). Para Indursky (1990) a denegaçăo discursiva refere-se a determinados saberes que existem dentro da própria formaçăo discursiva. $O$ sujeito năo reconhece esses saberes, de tal forma os denega. "[...] ao incidir sobre um elemento 
de saber que pode ser dito pelo sujeito do discurso, mas que, mesmo assim, por ele é negado, tal elemento permanece recalcado na formaçăo discursiva, manifestando-se em seu discurso apenas através da modalidade negativa" (INDURSKY 1990, p. 118). O discurso do sujeito é determinado por uma formaçấo discursiva que na linguagem representa as formaçóes ideológicas que lhe săo correspondentes (PECHEUX, 1969, 2009). Se a psicanálise e a $A D$ aproximam-se por conceber um sujeito cindido, é em funçăo desse sujeito que ambas as teorias se diferenciam. Para a AD, o sujeito é descentrado, fragmentado e ideologicamente constituído.

[...] Para que a negaçăo produza um efeito de denegaçăo, ocorre a ocultaçăo de um comportamento admitido pela FD a que o enunciado está vinculado. Esse funcionamento discursivo aponta para as relaçóes que a FD estabelece com sua interioridade: a denegaçáo revela o modo como o sujeito relaciona-se com a FD que o afeta (INDURSKY, 1990, p.121).

O sujeito é atravessado por muitas formaçōes discursivas e determinado(s) saber(es) estâo inscrito(s) em sua formaçâo discursiva dominante, porém ele nâo os reconhece, e esse elemento do saber apresenta-se no fio de seu discurso através da negaçăo.

Fedatto (2015) aborda a negaçâo, no texto "sobre as possibilidades de negaçâo na imagem e alguns desdobramentos teórico-analíticos". Embora a materialidade discursiva seja a imagem, é interessante quando a autora afirma que uma das funçōes da negaçăo é assegurar a primazia do inconsciente sobre o eu, da falha sobre o fechamento do ritual, da contradiçăo sobre a evidência. A negaçăo funciona quando há năo ditos que significam muitas vezes como censura, oposiçăo, apagamento. Acredita-se que a de (negaçăo) produz um sentido de apagamento.

No batimento entre descriçăo e interpretaçăo percebe-se na superfície linguística e pelo viés da memória discursiva no discurso de Mourăo e Camargo o efeito de apagamento sobre o racismo neles próprios e no país. Neste entrecho analisa-se no próximo item o corpus discursivo que constitui este trabalho.

\section{TRABALHO ANALÍTICO NUM CORPUS DISCURSIVO}

Este artigo promove um gesto de leitura, interpretaçăo e análise acerca do discurso do Presidente da Fundaçăo Palmares, Sérgio Camargo, a respeito do assassinato de Joáo Alberto Ferreira de Freitas, ocorrido em 20/11/2020 e do discurso do vice-presidente da República, ocorrido na mesma data. Assim utilizou-se um vídeo extraído do site g1 globo, e reportagens dos sites da Uol, JC e Istoé montando-se recortes discursivos: o do vice-presidente e o de Sérgio Camargo.

É importante considerar que o discurso de Sérgio Camargo se caracteriza por sempre se envolver em polêmicas. A sua nomeaçáo chegou a ser suspensa por fazer declaraçôes incompatíveis com o cargo. No site do g $1^{4}$ aparece um áudio ilegalmente gravado, onde Sergio Camargo em reuniăo, no dia 30/04/2020, a portas fechadas, conversa com dois servidores a respeito do desaparecimento de seu celular corporativo. Quando questionado sobre quem poderia ter feito isso, Sérgio Camargo afirma: "[...] alguém que quer me prejudicar [...] o movimento negro, os vagabundos do 
movimento negro, essa escória maldita". Na mesma reuniăo menosprezou Zumbi dos Palmares e se manifestou contra o Dia da Consciência Negra. No entanto, este artigo se deterá ao discurso de Sérgio Camargo em relaçâo à açăo violenta e mortal ocorrida no Carrefour contra um cliente negro.

Em site do Jornal do Commercio, o presidente da Fundaçăo Palmares afirma que o homem negro morto no Carrefour era marginal e nâo representa os "pretos honrados". Sérgio Camargo tem como posiçăo sujeito preservar as manifestaçôes afro-brasileiras, mas se posiciona de forma antagônica. Desde a posse, ameniza e/ ou nega o racismo presente no Brasil, pois identifica-se a outra posiçấo sujeito sem que tenha consciência disso. Em 2019, chegou a ser afastado do cargo por ordem do juiz federal Emanuel José Matias Guerra. O magistrado alegou que a gestăo de Sérgio Camargo colide com a equidade, proteçấo, valorizaçăo da cultura afro brasileira. Em junho de 2020, a ministra do Superior Tribunal de Justiça Regina Helena Costa negou pedido da Rede de Sustentabilidade para afastar Sérgio Camargo do cargo. A solicitaçáo decorre do fato de que o presidente da Fundaçáo Palmares revela publicamente opiniōes dissonantes às finalidades da Instituiçâo. A Fundaçâo Palmares possui práticas, liturgias que movimentam uma discursividade e determinam as posiçôes com as quais os sujeitos se inscrevem para enunciar.

Analisa-se abaixo o discurso do vice-presidente do Brasil e comentários de dois internautas que funcionam como unidades de sentido em relaçâo à situaçâo.

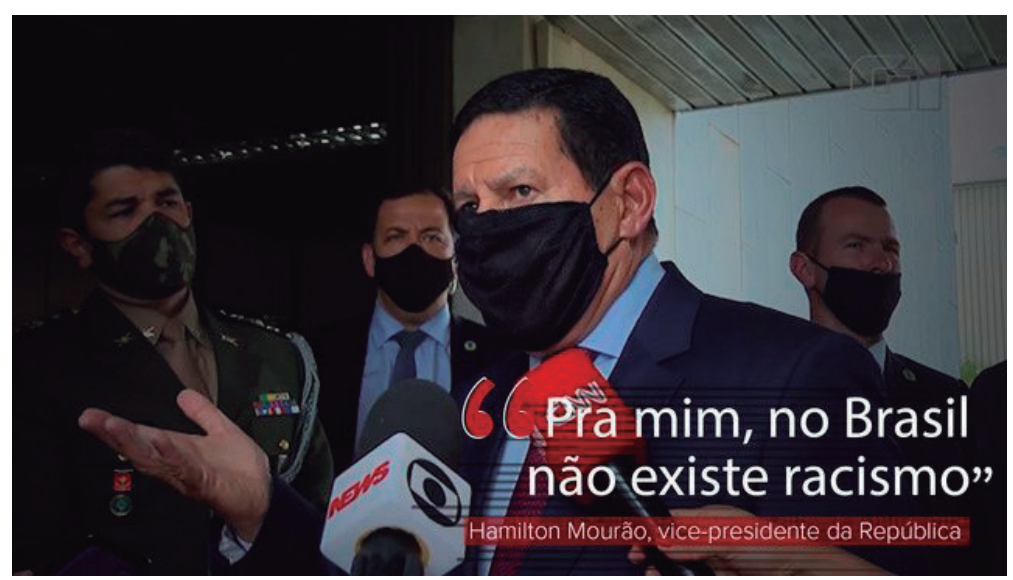

“É lamentável né?, é lamentável isso aí, é lamentável. Em princípio é uma segurança totalmente despreparada para atividade que ele tem que fazer. Năo, pra mim no Brasil năo existe racismo, isso é uma coisa que querem importar aqui pra o Brasil. Isso năo existe aqui. Eu digo isso pra você. Eu morei nos Estados Unidos, racismo tem lá. Eu morei 2 anos nos Estados Unidos, na minha escola que eu morei lá o pessoal de cor andava separado e eu nunca tinha visto isso aqui no Brasil, mais ainda, o pessoal de cor sentava atrás do ônibus e năo sentava na frente do ônibus, aqui năo existe isso [..]."

“[..] As formas linguísticas estâo entre os elementos de combate que mais se destacam, na medida em que se acredita [...] que reproduzem uma ideologia que segrega em termos de classe, sexo, raça e outras características físicas e sociais objeto de discriminaçăo [...]" (POSSENTI, 95, p.125). A AD aponta para o linguístico, intervém como pressuposto e a língua é lugar material onde se produzem os efeitos de sentido. 
É importante analisar a posiçăo que o sujeito social ocupa em seu discurso, onde o linguístico aponta para exterioridade constitutiva inscrita na historicidade. O vice-presidente Hamilton Mourâo enuncia de uma posiçâo sujeito de aliado a uma formaçâo ideológica bolsonarista, como era de se esperar no discurso que emana desse lugar. Assim, a posiçaáo sujeito de Mouráo é ideologicamente marcada pelo discurso dominante, que venceu a luta no interior do Aparclho ideológico do Estado (AIE). Nessa relaçăo de forças, os sentidos produzidos pelo seu discurso săo regulados pelo lugar social ocupado por ele. Afetada pela ideologia de extrema direita, identifica-se com o conservadorismo, racismo, sendo este oficialmente "elidido socialmente". Além disso, quando Mourăo diz "isso é uma coisa que querem importar aqui para o Brasil", fica a questăo: quem quer importar o racismo para o Brasil? Os jornalistas? O povo? Há um silenciamento ao racismo estrutural presente no país. O discurso de vice-presidente aponta para o já-dito, como defende Pêcheux (1969, 1999, 2009), ao afirmar que algo fala antes, em outro lugar, independente e diferentemente. Acionando a memória discursiva, os saberes mobilizados apontam que o termo "de cor" marca a identificaçâo a uma formaçăo discursiva racista. Ao dizer que morou nos Estados Unidos e o racismo lá existe porque os negros sâo segregados fisicamente, produz um efeito de sentidos de que o racismo significa separaçấo física e nâo apenas social, que nos Estados Unidos é assumido, o que nâo ocorre no Brasil. Pelo acionamento da memória discursiva, o termo linguístico de "cor" enunciado desde os mais remotos tempos, faz ressoar sentidos de segregaçăo, inferiorizaçăo, do ser negro, homogeneizando cor e raça como algo que coloca o sujeito à margem de seus direitos. Conforme Guimarâes (1995, p. 42):

assimé o racismo brasileiro. Sem cara, travestido em roupas ilustradas, universalista, tratando-se a si mesmo como anti-racismo, e negando como antinacional a presença integral do afro-brasileiro ou do índio-brasileiro. Para esse racismo, o racista é aquele que separa, năo o que nega a humanidade de outrem; desse modo, racismo, para ele, é o racismo do vizinho (o racismo americano).

Percebe-se, o discurso de Mourâo convergindo com a textualizaçăo de Guimarâes (1995). O vice-presidente, ao enunciar, năo diz apenas algo sobre o outro, mas também diz muito sobre si, sobre sua constituiçâo como sujeito.

O sujeito Mourăo está dominado por uma FD na qual racismo no Brasil náo existe. Além disso, nessa FD só há essa possibilidade de sentido. Nâo existem outras formas de racismo dentro dessa FD, que representa a ideologia dominante do Estado brasileiro. O discurso náo é literal, mas polissêmico, incompleto e, por isso, sujeito a falhas, derivas. $O$ vice-presidente se subjetiva como "elite" pela interpelaçăo ideológica, visto que morar e estudar nos Estados Unidos é privilégio para uma minoria. Mourâo (re)atualiza o já-dito sobre o racismo, inscrevendo este assunto numa memória atual. Apresenta na opacidade de seu discurso derivas, produzindo efeitos de sentido de que o Brasil é, sim, um país racista. Mourăo inscreve-se em uma FD que diz que o racismo no Brasil năo existe, interpelado por uma ideologia que produz esse efeito de evidência. $\mathrm{O}$ vice-presidente significa e se significa no movimento de seu discurso, sob a ilusâo da transparência da linguagem, pois a ideologia naturaliza sentidos produzindo o efeito de completude. Racismo é crime, é imoral (ALMEIDA, 2018). Como político, Mourăo produz em seu discurso efeitos de sentido de (des) conhecimento da constituiçáo, que 
em seu artigo $1^{\circ}$ (Direitos fundamentais), inciso VIII traz repúdio ao terrorismo e ao racismo e em seu artigo $5^{\circ}$ inciso XLIII (Dos direitos e garantias fundamentais) traz o racismo como crime inafiançável e imprescritível sujeito à pena de reclusáo. $O$ vice-presidente, ao enunciar: "é lamentável (...) em princípio é uma segurança totalmente despreparada" produz efeitos de sentido năo de repúdio ao racismo, crime por racismo, mas decorrência de uma segurança sem competência e năo vislumbra sequer o racismo como possibilidade. Na posiçăo sujeito ocupada por Mourấo e aliados, o racismo é aquele que existiu e existe nos Estados Unidos. Há uma naturalizaçăo dos negros em posiçóes subalternas, é um processo relacionado à aparência física, capacidade de consumo e circulaçâo social. Ser branco é atribuir identidade a outrem e negar sua própria identidade (ALMEIDA, 2018).

O funcionamento discursivo nos dizeres do presidente contrapóe-se ao discurso-outro que circula socialmente entre alguns brasileiros, o de que a democracia racial é um mito, principalmente por parte de alguns estudiosos. Mourăo redireciona seu discurso no sentido do que pode e deve ser dito em sua formaçăo discursiva, num mecanismo em que a afirmaçâo recalca no interdiscurso o discurso da formaçấo discursiva dissonante, ou seja, "apaga" o que nâo pode e deve ser dito. Conforme Indursky (2011, p.71):

[...] os sentidos, pelo trabalho que se instaura sobre a Forma-Sujeito, podem atravessar as fronteiras da FD onde se encontram, e deslizarem para outa FD, inscrevendo-se, por conseguinte, em outra matriz de sentido. Ao migrarem, esses sentidos passam a ser determinados por outras relaçóes com a ideologia [...].

A formaçăo discursiva pode sofrer deslizamentos e o sujeito migrar para outra FD, constituindo novos saberes e sentidos. Os dizeres de Mourâo marcam essa migraçăo de sentidos e saberes no discurso do vice-presidente. Ao dizer que o racismo năo existe no Brasil existe um năo dito que aponta para que o vice-presidente, o Brasil é racista. O enunciado negativo de Mourăo é a manifestaçâo de outro, afirmativo. A sua negaçăo produz o efeito de denegaçăo, pois ocorre uma ocultaçăo de um posicionamento aceito pela formaçăo discursiva a que o enunciado está vinculado

Do exposto, acionando a memória discursiva, a mídia, a imprensa fez circular e cristalizar sentidos de que Mourâo é racista e que apenas a segregaçâo física se configura como racismo, independente da violência física, simbólica, dentre outras.

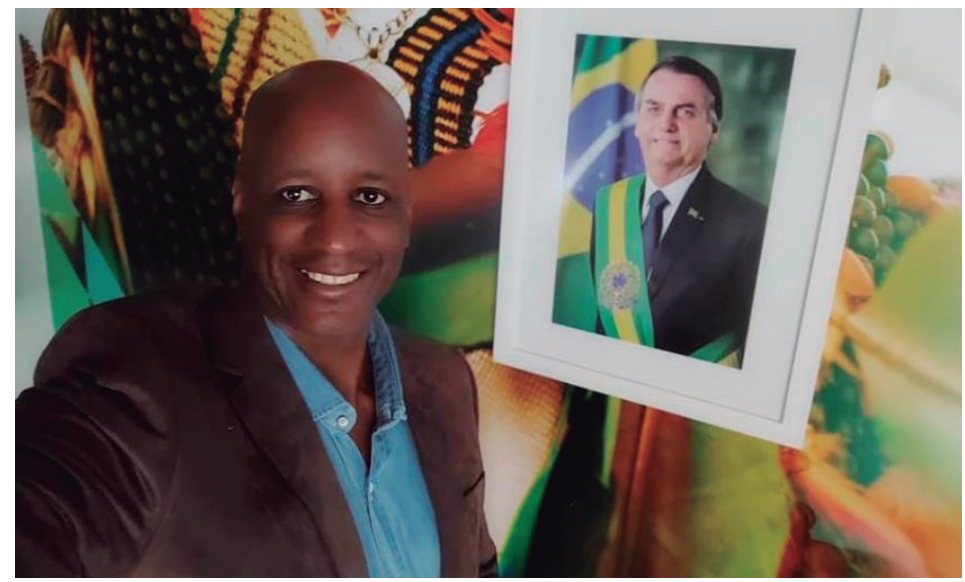


Năo existe racismo estrutural no Brasil; o nosso racismo é circunstancial - ou seja, há alguns imbecis que cometem o crime. A "estrutura onipresente" que dia e noite oprime e marginaliza todos os negros, como defende a esquerda, năo faz sentido nem tem fundamento. -- Sérgio Camargo (@sergiodireita1) November 20, 2020).

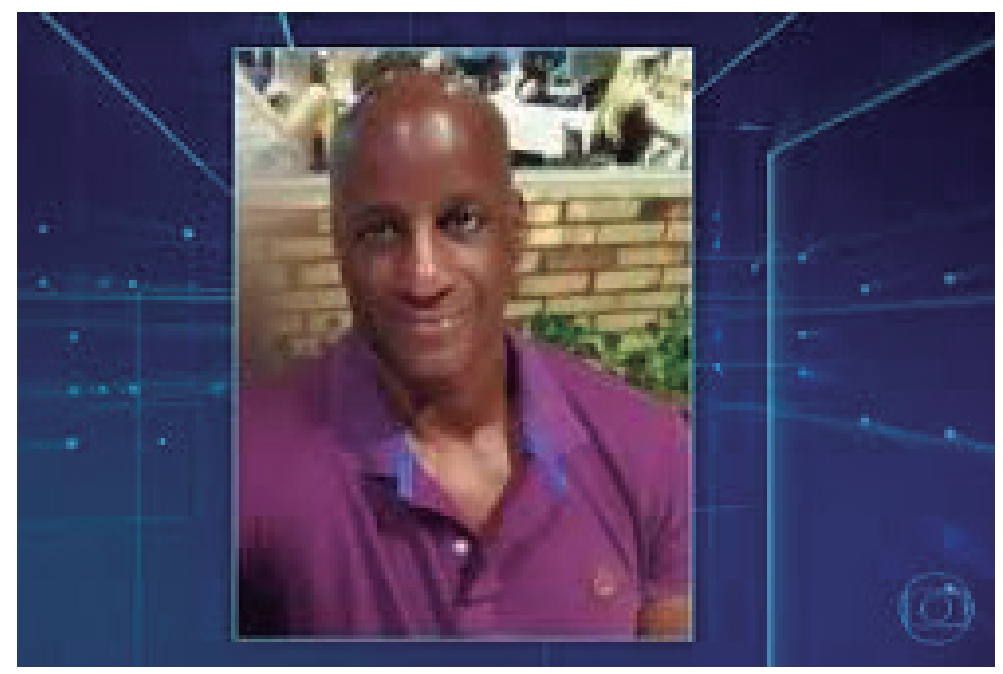

Questionado na reuniăo a respeito de quem poderia ter pegado o aparelho, respondeu:

Qualquer um. Eu exonerei três diretores nossos assim que voltei. Qualquer um deles pode ter feito isso. Quem poderia? Alguém que quer me prejudicar, invadindo esse prédio aqui pra me espancar. Quem poderia ter feito isso? Invadindo com a ajuda de funcionários daqui. O movimento negro, os vagabundos do movimento negro, essa escória maldita.

O discurso de Sérgio Camargo apresenta na superfície linguística termos que remetem ao "xingamento", escárnio, ironia, à crítica, ao dizer: "imbecis" e "esquerda" e ao enfatizar vagabundos, o sentido desliza para preguiçosos, ladrôes, marginais. A memória discursiva faz ressoar ecos de algo vindo de outro lugar, como defende Pêcheux (1969, 1999, 2009), há um năo-dito que se faz presente à referência de Deus, a expressâo 'onipresente'. Esse termo linguístico acessa uma rede de memórias de polêmicas sobre o PT que repercutiram negativamente no mundo e continuam reverberando até o momento vigente. Nas condiçôes de produçâo em que Sérgio Camargo enuncia, tocado pelas formaçóes imaginárias, o presidente da Fundaçăo Palmares pensa que por ser negro, alinhado ao governo bolsonarista, o leitor/ouvinte desacreditado do PT, conferirá crédito ao seu discurso. Conforme Pêcheux (1969) Orlandi $(1998,2013)$ nas formaçōes imaginárias o sujeito ocupa o lugar do ouvinte a partir do próprio lugar. O sujeito ocupa uma posiçăo e faz uma representaçáo de si, do outro, do outro em relaçăo a si, do referente. Sérgio Camargo produz o sentido que estando numa posiçăo sujeito de presidente da Fundaçâo Palmares, representante do movimento de luta contra o racismo e desigualdades raciais deveria estar inscrito numa FD anti-racista e nessa FD deve saber o que pode e deve falar em público. Ao afirmar que o racismo é circunstancial produz um sentido de estar "alheio" à conjuntura sócio histórica do país, de desconsideraçăo de marcas construídas socialmente ao longo de muitos anos. Interpelado pela FD bolsonarista, faz ressoar ecos de dizeres do branco 
e/ou negro racista. Acionando a memória discursiva, Sérgio Camargo em seu discurso inscrito na historicidade pela exterioridade constitutiva, produz, entre muitos efeitos de sentido, o de que o racismo "onipresente" é resultado de uma falácia que o PT forjou no imaginário dos sujeitos. Segundo Nunes (2006), a agressăo e discriminaçăo racial persiste sob o mito da democracia racial.

Conforme Pêcheux (1969, [1975], 2009), a ideologia se materializa no discurso e o discurso se materializa na língua sendo está o lugar material onde se realizam os efeitos de sentido. Considerando que a discursividade (2012c, 2013) corresponde aos efeitos materiais da língua sujeita a falhas na história, os dizeres de Sérgio Camargo geram novas discursividades, visto que em seus enunciados, há falhas, deslizes. Ao dizer que qualquer um poderia ter pego seu celular, em seguida deixa a ausência se manter presente, o náo-dito de que os negros sâo ladrôes, espúrios, devem ser segregados. Sérgio Camargo apresenta na sua formulaçâo o negacionismo sempre presente no discurso do poder Executivo. Acionando uma rede de memória, o presidente da Fundaçăo Palmares retoma o já-dito acerca do discurso do presidente, quando ainda era deputado e candidato à presidência no site https://www.emaisgoias.com. br intitulado: "Supremo julga hoje denúncia de racismo contra Bolsonaro", em que foi denunciado pela Procuradoria Geral da República por apresentar dizeres racistas e manifestaçōes discriminatórias contra quilombolas, índios, gays, bissexuais, transsexuais, refugiados. Este fato teve repercussăo mundial e foi exposto pela mídia no dia 11/09/2018. Acionando a família parafrástica, o discurso de Sérgio Camargo produz sentidos de que a violência ocorrida no Carrefour foi normal, correta, justa ao dizer que Joăo Alberto Ferreira de Freitas nâo fazia parte "dos pretos honrados". 0 seu discurso deriva de raça para cor, e honrados desloca para sentidos de que a vítima era desonesta, marginal e mereceu a morte. A apologia à violência é algo que permeia o atual governo, no qual a desloca para o efeito de justiça, liberdade de expressáo. Há um eco do discurso do governo federal de que "bandido bom é bandido morto" Em seu discurso denega ${ }^{6}$ que o país náo é racista e produz efeitos de sentido de que o racismo está presente no Brasil. Ao afirmar que náo existe racismo, Sérgio Camargo, por meio da denegaçăo discursiva, năo "apaga" um saber que está em sua formaçăo discursiva. A negaçăo ocorre sobre um fato em que muito poderia ser dito, mas săo denegados por questôes políticas, sociais e econômicas. Camargo está inscrito numa formaçăo discursiva de extrema direita/racista em que se veicula como máxima náo existir racismo no Brasil.

Para Althusser (1985) quando há o “chamamento ei! Você aí! E o indivíduo dá uma volta de 180 graus em direçâo a quem chama, isso se constitui em um processo mais primário de interpelaçấo. Onde há reconhecimento e identificaçâo como atesta Modesto" (2018). Conforme Santos (2018), a interpelaçăo pretende colocar o sujeito em seu lugar social.

[...] ao interpelar pelo chamamento que tensiona a cor da pele-“olhe um preto" - um duplo funcionamento precisa ser destacado: i) primeiro, o sujeito é provocado, a

6 Parafraseando Orlandi (2011, p.257-258) quando aborda a retórica da denegaçâo, a autora afirma que o ouvinte acumula valores negativos como por exemplo ser racista corresponde a pecado, a um náo estar em harmonia com o Divino. Para afirmar que o Brasil é racista deve-se negar o negativo, ou seja, náo existe este pecado que é o racismo. 
partir de um estímulo externo, um olhar em terceira pessoa, a se reconhecer como preto, na medida em que ele é reconhecido pelo outro dessa forma - reconhecimento negativo e que coloca o interpelado em seu lugar; ii) depois disso, é importante notar como essa provocaçáo-chamamento desliza discursivamente passando a funcionar também como um xingamento, uma injúria racial, que acusa o sujeito de ser - ele é preto/ ele é culpado[...] (MODESTO, 2018, p. 136).

O discurso de Sérgio Camargo, produz entre tantos efeitos de sentido que Joáo Alberto Ferreira de Freitas é duplamente afetado pelo efeito da interpelaçăo que o culpabiliza por ser "preto" e "bandido". No discurso de Sérgio Camargo ressoam sentidos de que o aparelho repressivo do Estado configurado na violência do policial militar e do segurança do Carrefour significa e se significa como ordem e proteçấo e năo como arbitrariedade, barbárie. Os sentidos de policiamento racham com o esperado, mas circulam e fazem sentido em contextos sociais e políticos de segregaçâo. Parafraseando Santos (2018), há seguranças brancos que colocam sua branquitude a serviço do racismo.

Conforme Orlandi (2013) a AD năo trabalha com o que o texto quer dizer, mas como ele funciona, produz sentidos inscritos na historicidade. Como defende Pêcheux (2009, p. 158) "[...] o sujeito se "esquece" das determinaçóes que o colocaram no lugar que ele ocupa [...]". O discurso do presidente da Fundaçăo Palmares afetado pela equivocidade produz um efeito de apagamento de sua raça e sobre o que (deve) ria defender em "sua pasta". Identifica-se' aos saberes pertencentes a formaçâo discursiva bolsonarista. Conforme Possenti (1995), o racismo estando presente na sociedade, a possibilidade para tal leitura se acentua. Conforme Fedatto (2015), devemos procurar o náo que se diz e o náo que năo se diz, mas que também significam produzindo seus efeitos de sentido.

\section{CONSIDERAÇÕES FINAIS}

Este artigo elegeu duas materialidades discursivas para análise: 0 discurso do vice-presidente da República Hamilton Mourâo e o discurso do presidente da Fundaçâo Palmares, Sérgio Camargo. Para realizar um gesto de leitura, interpretaçâo e análise, o estudo mobilizou como dispositivo teórico e analítico a Análise do Discurso de linha francesa. Esse gesto teórico-analítico foi acerca da posiçăo sujeito de vice-presidente e presidente da Fundaçăo Palmares através de reportagens postadas em vídeos pelo gl globo, em que Mouráo e Sérgio Camargo fazem ressoar efeitos de sentido racista. Nos sites da uol, JC e istoé, dentre outros, o discurso de Sérgio Camargo também produz efeitos de sentido racista. Considerando que o linguístico intervém como pressuposto que é inscrito na historicidade e aponta para exterioridade constitutiva, esta determina na formaçăo discursiva o que pode e deve ser dito. As formaçóes discursivas e imaginárias de Mourăo e Sérgio Camargo, atravessados pela memória discursiva, produziram efeitos de crítica, ironia, arrogância e racismo. Para compreensăo do sujeito discursivo é necessário analisar o lugar social que ocupa. Os discursos de Mourâo e Sérgio Camargo convergem para uma dada realidade social. Por isso, este artigo trouxe discursos racistas historicamente marcados que funcionam como unidades de sentido em relaçăo à situaçăo, ao sujeito e à memória, que 
possibilita o já dito ser inscrito em um novo acontecimento, no movimento pendular entre descriçăo e interpretação.

Depreende-se que as posiçóes sujeito vice-presidente e presidente da Fundaçăo Palmares permitem que certos sentidos e saberes circulem, enquanto outros sejam interditados, a partir da formaçâo discursiva em que se inscrevem, ou seja, de extrema direita conservadora. Mourâo e Sérgio Camargo, ao afirmarem que náo existe racismo no Brasil, o fazem através da negaçăo. A memória discursiva é acionada por Mourâo, quando em seu discurso diz "pessoas de cor" (termo idêntico utilizado nos primórdios do racismo nos Estados Unidos, colored people) que produz efeitos de sentido de inferior, menor, e o năo-dito constitutivo de todo dizer, no discurso do vice-presidente, ao afirmar que o racismo năo existe no Brasil recrudesce sua existência.

O presidente da Fundaçăo Palmares, ao nomear os negros de escória maldita, vagabundos, que o racismo existe para uma minoria de imbecis e esquerdistas, polissemicamente seu discurso desloca de sua funçâo de defensor de manifestaçôes afro-brasileiras para representante do racismo estrutural no Brasil, onde o racismo apenas existe em sujeitos que săo da oposiçăo. 


\section{REFERÊNCIAS}

ALMEIDA, S. L. O que é racismo estrutural? Belo Horizonte, Letramento, 2018. Disponível em: <>. Acesso em: 20 nov. 2020.

ALTHUSSER, L. Ideologia e Aparelhos Ideológicos do Estado. Săo Paulo: Martins Fontes: Lisboa, 1985.

BERNARDINO, J. Açâo afirmativa e a rediscussāo do mito da democracia racial no Brasil. Revista Estudos Afro-asiáticos, ano 24, n.2, 2002, p.247-273. Disponível em: 〈>. Acesso em: 20 nov. 2020.

BRASIL DE FATO. Sete vezes em que o Carrefour atuou com descaso. Disponível em: <.> Acesso em: 22 nov. 2020.

BRASIL. CONSTITUIÇĀO 1988. Disponível em: <http://www.planalto.gov.br/ccivil_03/ constituicao/constituicao.htm>. Acesso em: 22 nov. 2020.

CAZARIN, E. A. Interlocuçâo discursiva: a afirmaçăo funcionando como negaçăo. In: ERNST-PEREIRA, Araci; FUNCK, Susana B. A leitura e a escrita como prática discursiva. Pelotas: Educat, 2001, p.133-152.

EMAISGOIÁS. Supremo julga hoje denúncia de racismo contra Bolsonaro. Disponível em: https://www.emaisgoias.com.br/supremo-julga-hoje-denuncia-de-racismo-contra-bolsonaro/. Acesso em: 11 janeiro 2021.

FEDATTO, C. P. Sobre as possibilidades de negaçăo da imagem e alguns desdobramentos teórico-analíticos. Revista ALED, v.15, n.2, p.27-37

Ferreira, M. C. L. Análise do Discurso e suas interfaces. O lugar do sujeito na trama do discurso. ORGANON - Revista do Instituto de Letras da UFRGS. v.24, n.48, 2010. Disponível em: 〈https://seer.ufrgs.br/organon/article/view/28636/17316〉. Acesso em: 20 nov. 2020.

G1 GLOBO. no Brasil, năo existe racismo, diz Mourăo sobre assassinato de homem negro em supermercado. Acesso em: <https://g1.globo.com/politica/noticia/2020/11/20/ mourao-lamenta-assassinato-de-homem-negro-em-mercado-mas-diz-que-no-brasilnao-existe-racismo.ghtml>. Acesso em: 20 nov. 2020.

GUIMARÅES, A. S. A. Racismo e anti-racismo no Brasil. Disponível em: <>. Acesso em: 22 dez. 2020.

INDURKY, F. Polêmica e denegaçăo: dois funcionamentos discursivos da negaçáo. Caderno de Estudos linguísticos, Campinas, v19, p.117-122, jul/dez, 1990. Disponível em: 〈>. Acesso em: 22 dez. 2020.

INDURSKY, F. A memória na cena do discurso. In: ; MITTMANN, S.; FERREIRA, M. C. L. Memória e História na/da Análise do Discurso. Campinas, SP: Mercado de Letras, 2011, p. 67-88.

Interpelaçâo ideológica e tensâo racial: efeitos de um grito. Modesto, Rogério. Littera Online, Programa de Pós-Graduaçâo em Letras, Universidade Federal do Maranhâo, v.9, n. 17, 2018, p.124-145. Disponível em: <http://www.periodicoseletronicos.ufma.br/ index.php/littera/article/view/ 10378>. Acesso em: 22 dez. 2020. 
ISTOÉ. Năo existe racismo no Brasil", diz Mouráo após morte de negro em supermercado. Disponível em: <https://istoe.com.br/nao-existe-racismo-no-brasil-diz-mouraosobre-assassinato-no-supermercado/>. Acesso em: 20 nov. 2020.

MBEMBE, A. Crítica da razăo pura. Traduçăo Marta Lança. Lisboa, 2014. Disponível em: $\quad<$ https://edisciplinas.usp.br/pluginfile.php/4117908/mod_resource/content/1/ MBEMBE\%2C\% 20Achille.\%20Cri\%CC\%81tica\%20da\%20raza\%CC\%83o\%20negra. pdf>. Acesso em: 20 nov. 2020.

NASCIMENTO, A. 0 genocídio do negro brasileiro: processo de um racismo mascarado. Paz e Terra, Rio de Janeiro, 1978. Disponível em: <https://afrocentricidade.files.wordpress.com/2016/ 04/o-genocidio-do-negro-brasileiro-processo-de-um-racismo-mascarado-abdias-do-nascimento. pdf>. Acesso em: 22 dez. 2020.

NUNES, S. S. Racismo no Brasil: tentativas de disfarce de uma violência explícita. Revista Psicologia, USP, v.17, n.1, 2006, p.89-98.

NUNES, S. S. Racismo no Brasil: tentativas de disfarce de uma violência explícita. Disponível em: 〈https://www.scielo.br/pdf/pusp/v17n1/v17n1a07.pdf〉. Acesso em: 22 nov. 2020.

OLIVEIRA, A. S.; CARVALHO, A. R. A desigualdade racial no Brasil: o racismo estrutural e o determinismo social. Revista Jurídica Direito, Sociedade e Justiça, v.5, n. 1, nov/ dez, 2017. Disponível em: <https://periodicosonline.uems.br/index.php/RJDSJ/ article/ view/2242>. Acesso em: 20 nov. 2020.

ORLANDI, E. P. Análise de Discurso: princípios e procedimentos. Campinas: Pontes, 2013.

ORLANDI, E.P. Discurso e argumentaçăo: um observatório do político. Fórum Linguístico, v.1, n.1, p.73-81， 1998. Disponível em:<http:/C:/Users/PMRecife/Downloads/ 6915-Texto\%20do\%20 Artigo-20890-1-10-20080923\%20(4).pdf>. Acesso em: 22 nov. 2020.

ORLANDI, E. P. Discursos e museus: Da memória e Do esquecimento. Revista entremeios, v.9, julho, 2014, p.1-8. Disponível em: <>. Acesso em: 22 nov. 2020

ORLANDI, E. P. Discurso e leitura. 9. ed. Săo Paulo: Cortez, 2012b.

ORLANDI, E. P. Discurso e texto. Formulaçăo e circulaçăo dos sentidos. 4. ed. Săo Paulo: Pontes, 2012c.

ORLANDI, E. P. Discurso em análise. Sujeito, sentido, ideologia. 2. ed. Campinas: Pontes Editores, 2012a.

PECCHEUX, M. Análise automática do discurso (AAD-69). In: GADET, Françoise; HAK, Tony (orgs). Por uma análise automática do discurso. Uma introduçâo à obra de Michel Pêcheux. 5. ed. Campinas, SP: Editora da Unicamp, 2014, p. 59-96.

PÊCHEUX, M. Discurso: estrutura ou acontecimento. 5. ed. Campinas: Pontes, 2008.

PÊCHEUX, M. Papel da memória. ACHARD, Pierre et al. (orgs.) Papel da memória. Nunes Campinas: Pontes, 1999.

PÊCHEUX, M. Semântica e discurso. 4. ed. Campinas: Editora da UNICAMP, 2009, p. 137-281. 
PÊCHEUX, M.; FUCHS, C. A propósito da análise automática do discurso: atualizaçăo e perspectivas (1975). In: GADET, Françoise; HAK, Tony (orgs). Por uma análise automática do discurso. Uma introduçâo à obra de Michel Pêcheux. 5. ed. Campinas, SP: Editora da Unicamp, 2014, p.159-231.

POSSENTI, S. A linguagem politicamente correta e a Análise do Discurso. Revista de Estudos da Linguagem. Ano 4, v.2, jul/dez, 1995, p.125-142. Disponível em: 〈>. Acesso em: 20 nov. 2020.

SANTOS, R. L. M. "você matou meu filho" e outros gritos: um estudo das formas de denúncia. (TESE) Doutorado. Instituto de Estudos da Linguagem da Universidade Estadual de Campinas. 2018. $244 \mathrm{f}$.

Sérgio Camargo diz que homem morto no Carrefour "năo representa os pretos honrados". Disponível em: <https://jc.ne10.uol.com.br/brasil/2020/11/12001958-sergio-camargodiz-que-homem-morto-em-supermercado---nao-representa-pretos-honrados.html>. Acesso em: 19 dez. 2020.

Sérgio Camargo diz que homem morto no Carrefour "náo representa os pretos honrados". Disponível em:〈https://istoe.com.br/sergio-camargo-diz-que-homem-morto-no-carrefour-nao-representa-os-pretos-honrados/>. Acesso em: 22 dez. 2020.

Sérgio Camargo nega a existência de racismo estrutura:'năo tem fundamento'. Disponível em: <https://noticias.uol.com.br/politica/ultimas-noticias/2020/11/20/sergio-camargo-diz-que-racismo-estrutural-nao-tem-sentido-nem-fundamento.htm>. Acesso em: 19 dez. 2020.

Sérgio Camargo nega existência do racismo estrutural: 'năo tem fundamento'. Disponível em: <https://noticias.uol.com.br/politica/ultimas-noticias/2020/11/20/sergio-camargo-diz-que-racismo-estrutural-nao-tem-sentido-nem-fundamento.htm>. Acesso em: 22 dez. 2020.

SINPRO. negros ocupam apenas um décimo das cadeiras no poder legislativo do brasil. Disponível em: <https://www.sinprodf.org.br/negros-ocupam-apenas-um-decimo-dascadeiras-no-poder-legislativo-do-brasil/>. Acesso em: 11 jan. 2021.

VEJA. A segregaçăo, no Brasil, é social, racial e dissimulada. Disponível em: ‘ . Acesso em: 20 nov. 2020. 